\title{
心不全の病態学における生理学と分子生物学： 種々の心血管作動性物質の病態生理学的役割を中心に
}

筑波大学臨床医学系循環器内科宫 内莒

\section{はじめた}

心不全の分野に扔いて, 従来からの生理学的研 究手法に加え, 分子生物学的手法の導入がさかん に行われるようになり，心不全に対する考え方に 大きなインパクトを与えてきている.

心不全における交感神経系の活性化は，心筋の 収縮力低下に対する代償作用として働く反面，そ れが過㮃になると心筋酸素需要の増大，カルシウ 厶過剩流入によるカルシウム過負荷, $\beta$ 受容体の down-regulation による反応性の低下など 2 次的 な増悪因子として働く

一方，レニン・アンジオテンシン (RA) 系の 種々の構成要素の存在が心蔵で証明され, さらに 心筋組織 RA 系が不全心に括いて六進すること が分子生物学的手法を用いた研究にて報告されて いる．また，アンジオテンシンIIは，不全心にお いて心筋細胞と線維芽細胞の双方に作用して心筋 のリモデリング (心筋細胞の肥大と間質の線維化 など）を引き起こすことが報告されている，そし て，アンジオテンシン変換酵素阻害薬が心不全患 者の予後を改善させる機序の 1 つとして，心筋 組織のリモデリングの抑制が考えられている.

一方，強力な血管収縮物質であるエンドセリン (ET)-1 は心筋細胞でも産生され，心筋に対して 陽性変力作用や心肥大作用, 心筋細胞傷害作用を 有する．われわれは先に，不全心筋にて ET-1
の発現が mRNA レベルおよびペプチドレベルと もに著明に増大し，ET 拮抗薬の長期投与が慢性 心不全ラットの生存率を著明に改善することを報 告した.

本稿にて，種々の心血管作動性物質の病態生理 学的役割を中心に，心不全の病態学における生理 学と分子生物学について述べたい.

心不全の病態学における生理学と 分子生物学と心血管作動性物犋

\section{1. エンドセリン}

エンドセリン (endothelin: ET) は，1988年, 血管收縮活性を指標として，ブタ大動脈内皮細胞 培養上清から単離精製されたペプチドである ${ }^{1)}$ 。 ET は21残基のアミノ酸より構成され，その前駆 体であるビッグエンドセリンから ET 変換酵素 (ECE-1, ECE-2 が同定されている）によって切 り出される. ET ファミリーには, ET-1 · ET-2 · ET-3 と呼ばれるアイソフォームが存在し ${ }^{2)}$ ，ま た異なったリガンド親和性を有する 7 回膜貫通 型の 2 種類の $\mathrm{G}$ 蛋白共役受容体 $\left(\mathrm{ET}_{\mathrm{A}}\right.$ 受容体, $\mathrm{ET}_{\mathrm{B}}$ 受容体）が存在する ${ }^{3,4)}$. ET-1 は，血管内 皮細胞や心筇細胞5)のみならず全身の諸葴器の種 々の細胞に㨟いても産生され，オートクライン, パラクラインとして働き，血管収縮作用1,6 8) や 血管平滑筋増殖作用 - 心筋肥大作用9,10) - 陽性変

[Key words ] 心不全, 生理学, 分子生物学, 心血管作動性物質 
時変力作用 ${ }^{11,12)}$ ・ 心筋傷害作用 ${ }^{13,14)}$ といった心血 管系への作用を有する．以下に，心不全における ET の病態生理学的役割について述べたい.

われわれは1989年に，急性心筋梗塞による心 不全患者において，ET-1 とその前駆体である big ET-1 の血中濃度が著明に増加していること を見いだした ${ }^{15)}$.その後, 高頻拍ペーシングに よるイヌの心不全モデル ${ }^{16,17)}$ や胸部下大静脈結禁 によるイスの心不全モデルにおいて ${ }^{18)}$ 血中 ET-1 濃度が上昇していることが報告された。ヒトでも 心筋梗塞後のうっ血性心不全や非虚血性心疾患に よる慢性心不全患者において，血中 ET-1 濃度 が上昇していることが報告されている。 またわれ われは, 先天性心疾患に伴う心不全患者にて血中 ET -1 濃度が著明に上昇し, 根治手術後その值が 正常化することを報告している19).

その後の検討から，血中 ET-1 濃度の上昇は 肺動脈圧や全肺血管抵抗の増加と相関しているこ とが明らかにされ20)，そして，血中 ET-1 濃度 の増加は, NYHA の心機能分類と相関している ことが報告された ${ }^{21 \sim 23)}$.これらのことより， ET -1 遺伝子の発現調節機構に大きな興味がもたれ る.

ヒト ET-1 遺伝子は，第 6 染色体に連座し， 5 つのエクソンと 4 つのイントロンから構成され, 全長約 $5.5 \mathrm{~kb}$ である. ET-1 遺伝子には急性期 反応調節領域 (APRRE) と呼ばれる cis 配列 (CTGGGA) がいくつか存在する.この配列はス トレスに対する急性応答としての ET-1 遺伝子 の迅速な発現に関与しているのもと推察される.

ET-1 遺伝子の $5^{\prime}$ 隣接領域には AP-1 結合部位 と呼ばれる cis 配列 (GTGACTAA) が 3 カ所存 在する。この領域は, TPA 応答領域 (TRE) と も呼ばれ, protein kinase C (PKC) によって活 性化される.

現在, AP-1 部位には DNA 結合蛋白であるプ ロトオンコジーン産物のヘテロダイマーが転写因 子として作用して, mRNAへの転写が促進され ると考えられている. また, 転写後レベルの調 節因子について以下に記す．ET-1 遺伝子の $3^{\prime}$
非翻訳領域には, ATTTA モチーフの繰り返し 配列がみられる。これに対応する mRNAの AUUUA 配列はある種のサイトカインや核蛋白 でもみられ， mRNAの不安定化に関与している. ET-1 mRNA の半減期は約 15 分と短く, その代 謝回転がきわめて早く行われているといえる。ま た, ET-1 mRNAの分解は蛋白合成阻害薬シク ロヘキサミドによって抑制され， ET-1 mRNA が著増する。これは mRNA 発現に対する抑制蛋 白の合成が阻害されるためと考えられる．このよ うに ET-1 遺伝子は転写後の調節を受けている.

われわれは，心筋梗塞の手術を行って作製した ラットの心不全モデルを用いて ET-1の産生部 位を検討したところ, 非梗塞部不全心筋 ${ }^{24)}$ とう っ血肺 ${ }^{25)}$ において著明な ET-1 の産生増加が認 められた。一方, 血管が豊富な臓器である腎蔵で の産生増加は認められなかった ${ }^{24,26)}$ (図 1). 以上 より, 心不全という病態に打けるET-1 の産生 増加はある蔵器に特異的であることが示唆され， 特に心臓と肺における産生増加が著しいと考えら れた. また不全心筋では両エンドセリン受容体数 も増加して抢り27)，不全心筋においてエンドセ リン系の活性化が生じていることが示唆された。

われわれは次に，心不全の不全心筋において増 加した ET-1 が，心機能をどのように修飾して いるのか調べるために，心不全モデル動物を用い て検討した ${ }^{24)}$. 慢性心不全のモデルは，ラット に左冠動脈結禁術を行い心筋梗塞を作製すること により得た．むず心不全ラットに $\mathrm{ET}_{\mathrm{A}}$ 受容体拮 抗薬である $\mathrm{BQ}-123$ を急性投与したところ，心拍 数は有意に減少し, 左室 $+\mathrm{dP} / \mathrm{dt}_{\max }$ も有意に低 下した.よって，心筋で ET-1 の産生が充進し た心不全状態では, 増加した ET-1 は心拍数の 上昇および心筋收縮力の増大を引き起こしてお り，心機能維持に関与していることが示唆され た.

そしてわれわれは，これらの不全心筋における エンドセリン系の活性化が心不全の進展にどのよ う関与しているかを検討するために, $\mathrm{ET}_{\mathrm{A}}$ 受容 体拮抗薬である BQ-123（7.5 mg/日）を冠動脈 
a

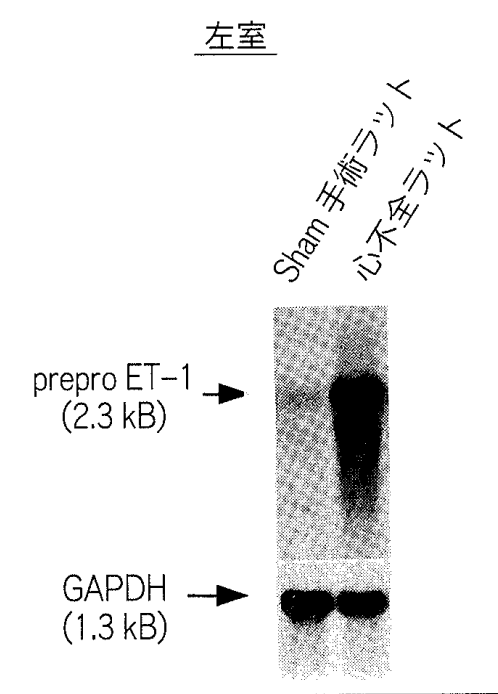

腎

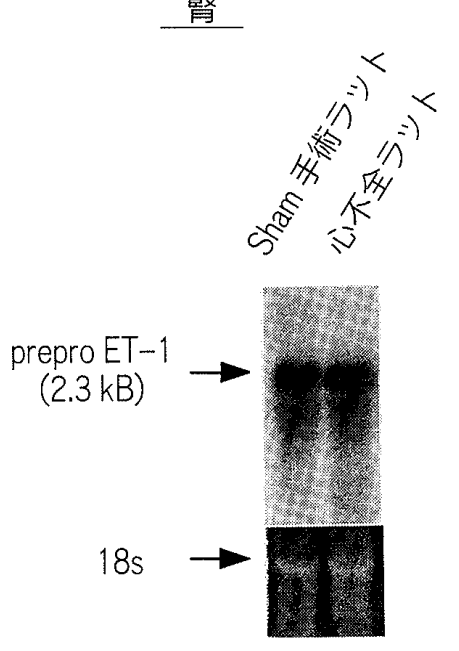

b

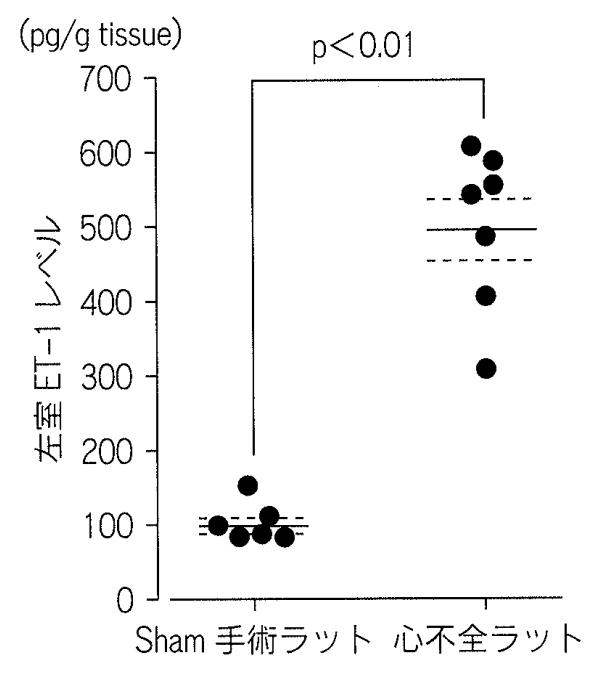

図 1 心不全ラットの心臟・腎臟におけるエンドセリン (ET)-1 の産生

ET-1の mRNA の発現（図a）およびペプチド（図 b）は，心不全ラットの左室において著明に増大していた. しかし，心不全ラットの腎缄における ET-1 mRNA の発現（図 a) はSham 手術群のむのと変わらなかった.

(文献26より引用)

結禁後10日目から 3 力月間このモデルに持続的 に投与した (CHF+BQ-123群). 対照として同 モデルに生理食塩水のみを投与した $(\mathrm{CHF}+\mathrm{sa}-$ line 群). CHF 群に対する BQ-123の長期投与に より, 生存率は著明に改善し, 3 力月後の生存率 は，生食投与群の $43 \%$ に対し，BQ-123投与群で は85\%であった ${ }^{26)} .3$ カ月後の血行動態は, $\mathrm{BQ}$ 123 投与群では左室 $+\mathrm{dP} / \mathrm{dt}_{\max }$ 低下の改善, 左室 拡張終期圧上昇の改善, 肺動脈圧および中心静脈 圧上昇の改善が認められた。ささらに $\mathrm{BQ}-123$ の長 期投与は，心筋梗塞後の心内腔の拡張や残存心筋 の肥大などとして観察される心室りモデリングの 進展を抑制していることが観察された ${ }^{26)}$ 。これ らの結果から，不全心筋におけるエンドセリン系 の活性化は，短期的には心機能維持に関与してい るが，長期的には心不全の悪化に大きく関与して いることが示唆された. そして $\mathrm{ET}_{\mathrm{A}}$ 受容体拮抗 薬の長期投与により，心不全の増悪を抑制できる ことが示唆された。

ET 受容体拮抗薬が心不全の進展を抑制するメ カニズムとして，ET-1 の心筋傷害作用や心肥大 作用を遮断することがその一因であると推察され
た. なた内因性 ET-1 による陽性変時 - 変力作 用を ET 受容体拮抗薬が遮断することにより，心 筋仕事量が減少することもそのメカニズムの一因 となりうることが推察された．さらに心不全の 分子マーカーであるANPやミオシン重鎖の mRNA の発現变化が抑制され ${ }^{28)}, \mathrm{Ca}^{2+}$ 調節蛋白 である心筋小胞体 $\mathrm{Ca}^{2+}$-ATPase やリアノジンレ セプタの mRNA の発現変化も抑制される29)こと から，ET 受容体拮抗薬の長期投与は，心蔵が不 全心筋へ移行するさいに生じる質的変化を，遺伝 子レベルから改善することが示唆された.

われわれは，心不全を呈する心筋症ハムスター においても，心缄での ET-1 遺伝子の発現が進 行性に著明に増加し， $\mathrm{ET}_{\mathrm{A}}$ 受容体拮抗薬を長期 間投与したところ生存率や心機能の著明な改善が 認められることを報告している30,31)。ゆえに， ET 拮抗薬は，虚血性および非虚血性（心筋症な ぞ）による両者の心不全の治療薬になることが示 唆された，以上をまとめると，原疾患を問わず様 々な心不全モデルにおいて，ET系の著明な活性 化が認められ，特に不全心筋での ET 系の活性化 が病態の進展・増悪に関与していることが推察さ 
れる。

現在, 海外（ヨーロッパ，米国）において心不 全に対し，ET $\mathrm{T}_{\mathrm{A}}$ 受容体拮抗薬扔よび $\mathrm{ET}_{\mathrm{A} / \mathrm{B}}$ 受容 体拮抗薬の臨床治験が進行中である．以下にその 報告を紹介する．NYHA class III の慢性心不全 患者を, 無作為二重盲検法で placebo 群12名と $\mathrm{ET}_{\mathrm{A} / \mathrm{B}}$ 受容体拮抗薬であるボセンタン (Bosentan) $1000 \mathrm{mg}$ 投与群24名とに振り分け，それぞ 2 週間投与を行った ${ }^{32)}$. 投与前と投与開始 1 日目 および投与開始 2 週目に血行動態測定と体液性 因子の測定にて評価を行った。ボセンタン投与群 の 1 名は低血圧にて投与を中止し，2名では血行 動態の増悪がみられた。投与開始 1 日目（内服 24時間後）に，ボセンタン投与群では，体・肺 血管抵抗の低下，心拍出量の増加がみられ，2 週 間後にこれらの指標はさらに改善を認めた。 また placebo 群々比較し, 平均動脈圧, 肺動脈圧, 肺 動脈楔入王，右房压の低下を認めた ${ }^{32)}$ 。さらに， ボセンタン投与群では, 血中 ET-1 濃度の低下
が認められた32)。

一方，慢性心不全患者に対する ET 受容体拮抗 薬の長期投与の大規模臨床治験 ( $\mathrm{REACH}-1$ trial）の成果も発表されている33). NYHA class III $\mathrm{B} \sim \mathrm{N}$ の慢性心不全患者370名（虚血·非虚血性 を問わず）を対照群，ボセンタン $500 \mathrm{mg}$ 投与群 の 2 群に分け，自覚症状 - 心不全の悪化をエン ドポイントとして 6 カ月間観察した。その効果 は後半の 3 力月間に認められ，自覚症状 - 心不 全の悪化による入院などは，ボセンタン投与によ り有意に改善した。

われわれは，不全心筋における ET-1 遺伝子 の発現増大のメカニズムの解明のため，心筋細胞 のエネルギー代謝異常が関与しているかを, 培亘 心筋細胞を用いて検討したすすなわち，ラットの 培養心筋細胞に，ミトコンドリアの呼吸鎖の阻害 薬であるロテノンを添加して心筋エネルギー代謝 を障害し，in vitro の不全心モデルを作製した。 ロテノン添加により，ET-1 の発現は著明に増加

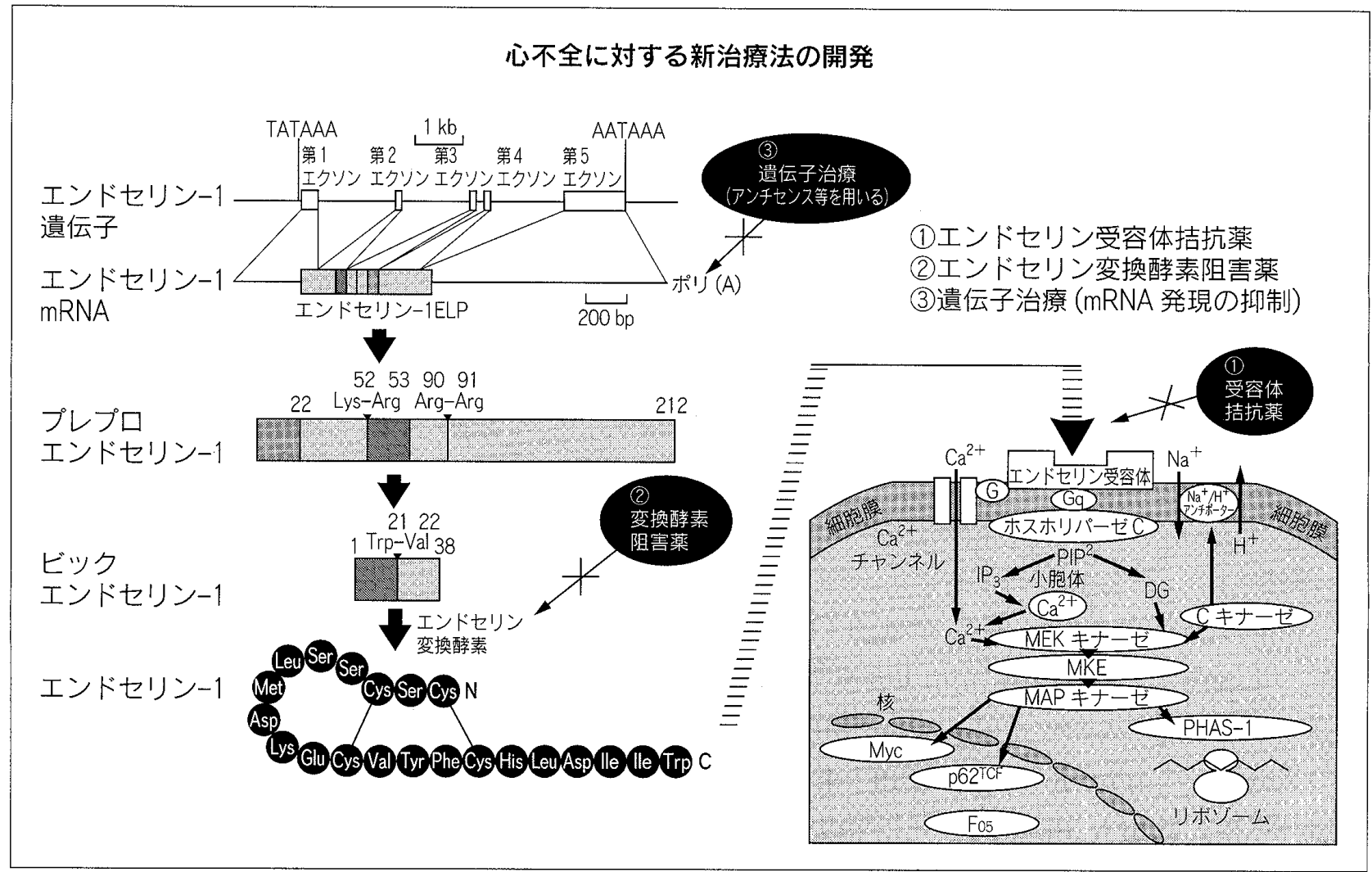

図 2 エンドセリン-1 系をターゲットにした心不全に対する新治療法の開発の研究のシェーマ

(1)エンドセリン受容体拮抗薬を用いた治療法（2)エンドセリン変換酵素阻害薬を用いた治療法（3)エンドセ リン mRNA の発現を抑制する遺层子治療（デコイやアンチセンスなどを用いる）などの可能性が考えられる. 
した．ゆえに，不全心筋におけるET-1の著明 な発現増加のメカニズムとして，神経体液因子や 機械的因子のほかに，心筋エネルギ一代謝の異常 も関与することが示唆された. ET-1の発現増大 はその陽性変力作用を介して心機能維持に関与す るという適応の要素を有するが, 過剰適応の要素 も有し, 持続的な心筋 ET-1 の発現增大は心筋 の破綻にも関与することが示唆された。

今後, $\mathrm{ET}$ 受容体拮抗薬どのタイプ $\left(\mathrm{ET}_{\mathrm{A}}\right.$ 受容 体拮抗薬や $\mathrm{ET}_{\mathrm{A} / \mathrm{B}}$ 受容体拮抗薬）が心不全によ り望ましいのか, また， ET 変換酵素阻害薬の長 期投与が心不全の生存率に対してどのような効果 があるのか，また，ET-1の遺伝子に対するアン チセンスやデコイ等を, in vivo 遺伝子導入法の 手法を用いて実際の心不全の心臓に導入して ET-1の遺伝子発現を抑制する遺伝子治療が，心 不全に対してどのような効果を及ぼすかなどを， 基礎・臨床両面からさらに研究することによっ て，ET-1の作用を遮断することを取り入れた慢 性心不全に対する新しい治療法が開発されること が期待される（図 2).

\section{2. アンジオテンシンII}

次に，アンジオテンシンII（A II）について 述べる．A II は，心肥大を誘発する因子として 重要な役割を果たしているぺプチド性因子の 1 つである. classical な A II の産生経路として, 肝蔵で合成され血中に分泌されるアンジオテンシ ノーゲンが，腎臓より産生分泌されるレニンと， 血管内皮細胞から産生されるアンジオテンシン変 換酵素 (ACE) により特異的分解を受け，A II が作られる経路がある。従来 A II は，上記のよ うに体循環系で産生されると理解されていたが, 近年アンジオテンシノーゲン, レニン, ACE と いったレニン・アンジオテンシン系 (RAS) の すべての構成要素が，心臓，血管壁，脳などの多 くの組織において存在することが明らかとなっ て，血中に分泌されるホルモンとしてだけでな く, オートクライン, パラクラインとして細胞や 組織レベルで働く生理活性物質であると考えられ
ている.

心筋細胞培養系に A II を添加すると, RNA 含 量の增加や蛋白合成が充進するが，圧負荷により 左室肥大を形成したラットでは，心筋の RAS が 元進し, 自然発症高血压ラット（SHR）では, アンジオテンシン変換酵素阻害薬により, 降圧と ともに，心肥大を著明に抑制することが報告され ている ${ }^{34)}$ ．また培養心筋細胞に伸展刺激をかけ ることにより，培養液中に A II が分泌されると の報告がある ${ }^{35)}$ 。この伸展刺激実験において，A II の作用を AT1 拮抗薬である CV-11974（TCV116の活性型）を用いて検討したところ，蛋白生 合成の充進が抑制され，また進展刺激により元進 する MAP キナーゼの活性化と c-fos の発現が, ともに半分以上抑制された。また SHRへの TCV-116の投与は，未投与群と比較して左心室 重量, 左心室壁厚の増加を抑えたことが報告され ている. 現在, RASのすべての構成要素は心筋 組織に存在することが分かっており，心臓はその 蔵器局所に抢いて，A II を生合成して心肥大作 用を行っていると考えられている.

心臓におけるアンジオテンシン受容体につい て，以下に記す。アンジオテンシン受容体は，大 きく 1 型 (AT1)， 2 型 (AT2)，4 型 (AT4) の 3 種類に分けられる. AT4 はその存在が確認さ れているものの, 受容体はまだクローニングされ ていない。このうち心蔵に拈いてはAT1 とAT2 が重要な役割を果たしていると考えられる．正常 な状態においてAT1 は心笳細胞, 心線維芽細胞 に存在し, AT2 は, 主に心筋細胞に存在してい るが，肥大心に扔いては，AT2 の発現が亢進し ていることが報告されている36).

心肥大 · 心不全時に, 心筋細胞表面には AT1 とAT2 の発現がともに充進している.A IIは， 心筋細胞膜に存在する $\mathrm{Gq}$ 蛋白と共役している AT1 を刺激することにより，細胞膜にあるホス ホリパーゼCが活性化し，それによりイノシト ールリン酸代謝物であるジアシルグリセロールの 産生元進が起こり，PKC を活性化する．PKCの 下流には，MAP キナーゼをはじめとする細胞増 
殖に重要な細胞内情報伝達系が存在し，それらが 次々にリン酸化されることにより，心筋細胞では 肥大が誘発されると考えられている。

また非心筋細胞の場合，A II は心肥大・心不 全時に非心筋細胞表面上のAT1を介して，細胞 増殖作用や，コラーゲンなどの細胞外マトリック スの生合成を充進し，肥大した心筋細胞を束ねて 収縮力を高めるといった適応現象を引き起こす。 確かに心肥大や心不全の初期に抢いては紐胞外マ トリックスの産生六進は有効に働くが，その過㮃 産生は，心臓の線維化を起こし，逆に心機能を低 下させることになる．最近，この増殖シグナルの 大部分が，EGFレセプタとカップリングして起 こっていることが，明らかとなった ${ }^{37) 。 つ ま り ~}$ A II の刺激は，AT1を介してすみやかに EGF レセプタのチロシンリン酸化を行い，ERK の活 性化, c-fos の発現を引き起こし，DNA 合成を六 進すると報告されている37).

一方，もう 1 つ主要なアンジオテンシン受 容体であるAT2 は，AT1 の作用と拮抗すると考 えられている.AT2のノックアウトマウスは， A II の投与により起こる血圧の上昇が野生型よ りも顕著であると報告されている38,39)．そして心 筋細胞に特異的に発現するように， $\alpha \mathrm{MHC}$ をプ ロモータとしてAT2 を過剩発現させたトランス ジェニックマウスは，胎児発育および，発育に問 題はないが，A II を投与しても心拍数の増加が 起こらず，血圧はかえって低下したと報告されて いる。これらの結果より，AT1の増加による陽 性変力作用が，AT2 を介した経路により抑制さ れると考えられる。 その作用としては，ホスファ ターゼ活性の上昇による ERK の不活性化やアポ トーシスの誘導が考えられている40)。しかしア ポトーシスの誘導については, AT1, AT2のど ちらを介しているのか意見の分かれているところ であり ${ }^{41)}$ ，今後の研究が期待される。

アンジオテンシンIIは，不全心において心筋細 胞と線維芽細胞の双方に作用して心筇のリモデリ ング（心筋細胞の肥大と間質の線維化など）を引 き起こすことが報告されている，そして，アンジ
オテンシン変換酵素阻害薬が心不全患者の予後を 改善させる機序の 1 つとして心筋組織のリモデ リングの抑制が考えられている，今後，アンジオ テンシン変換䤉素阻害薬とアンジオテンシン IIの 1 型受容体 (AT1) 拮抗薬のどちらが心不全の改 善により望ましいのか，アンジオテンシンIIの 2 型受容体（AT2）に作用する薬物が心不全にど のように影響を与えるかなど，この分野の研究の さらなる進展が望まれるところである.

\section{3. サイトカインなど}

上記以外の種々の心血管作動性物質, たとえ ば，インターロイキン-6，カルジオトロフィンー 1，アドレノメヂュリンなどが心不全においてど のような病態生理学的役割をしているのか，また それらに作用する薬物が心不全に対して有効なの か，それらの薬物が心不全の生命予後を改善する のかなど今後のさらなる研究が待たれるところで ある。

\section{おわりに}

心不全に関する生理学的研究手法に加え, 分子 生物学的アプローチを駆使することにより，心不 全をきたす疾患の早期診断，病態の把握，予後の 判定などがより正確に行える可能性がある。 た，心筋遺伝子産物の分子構造と機能との相関に 関する詳しい知見は，より特異的な作用を有する 新しい心不全治療薬の開発に結び付く可能性が期 待される。

\section{文}

1) Yanagisawa $M$, Kurihara $H$, Kimura $S$ et al: A novel potent vasoconstrictor peptide produced by vascular endothelial cells. Nature 1988; 332: 411-415

2) Inoue A, Yanagisawa M, Kimura S et al: The human endothelin family: three structurally and pharmacologically distinct isopeptides predicted by three separate genes. Proc Natl Acad Sci USA 1989; 86: 2863-2867

3) Miyauchi T, Masaki T: Pathophysiology of endothelin in cardiovascular system. Annu Rev Physiol 1999; 61: 
$391-415$

4) Rubanyi GM, Polokoff MA: Endothelins: molecular biology, biochemistry, pharmacology, physiology, and pathophysiology. Pharmacol Rev 1994; 46: 325-415

5) Suzuki T, Kumazaki T, Mitsui Y: Endothelin-1 is produced and secreted by neonatal rat cardiac myocytes in vitro. Biochem Biophys Res Commun 1993; 191: $823-830$

6) Miyauchi $T$, Tomobe $Y$, Shiba $R$ et al: Involvement of endothelin in the regulation of human vascular tonus: potent vasoconstrictor effect and existence in endothelial cells. Circulation 1990; 81: 1874-1880

7) Miyauchi $T$, Ishikawa $T$, Tomobe $Y$ et al: Characteristics of pressor response to endothelin -1 in spontaneously hypertensive and Wistar-Kyoto rats. Hypertension, 1989; 14: 427-434

8) Miyauchi $T$, Tomobe $Y$, Ishikawa $T$ et al: Vasoconstriction by endothelin-1 in resistance and conduit portions of isolated human mesenteric arteries. Eur J Pharmacol 1996; 303: 193-196

9) Shubeita HE, McDonough PM, Harris AN et al: Endothelin induction of inositol phospholipid hydrolysis, sarcomere assembly, and cardiac gene expression in ventricular myocytes: A paracrine mechanism for myocardial cell hypertrophy. J Biol Chem 1990; 265: 20555-20562

10) Miyauchi $T$, Yorikane $R$, Sakai $S$ et al: Contribution of endogenous endothelin-1 to the progression of cardiopulmonary alterations in rats with monocrotaline-induced pulmonary hypertension. Circ Res 1993; 73: 887-897

11) Ishikawa $T$, Yanagisawa $M$, Kimura $S$ et al: Positive inotropic action of novel vasoconstrictor peptide endothelin on guinea pig atria. Am J Physiol 1988; 255: H970-973

12) Ishikawa T, Yanagisawa M, Kimura $S$ et al: Positive chronotropic effects of endothelin, a novel endothelium-derived vasoconstrictor peptide. Pflügers Arch 1988; 413: 108-110

13) Stawski G, Olsen UB, Grande P: Cytotoxic effect of endothelin-1 during 'stimulated' ischaemia in cultured myocytes. Eur J Pharmacol 1991; 201: 123--124

14) Prasad MR: Endothelin stimulates degradation of phospholipids in isolated rat hearts. Biochem Biophys Res Commun 1991; 174: 952-957

15) Miyauchi $T$, Yanagisawa $M$, Tomizawa $T$ et al: Increased plasma concentrations of endothelin -1 and big endothelin-1 in acute myocardial infarction. 1989; Lancet 2: 53-54

16) Margulies $\mathrm{KB}$, Hildebrand FL, Jr, Lerman A et al:
Increased endothelin in experimental heart failure. Circulation 1990; 82: 2226-2230

17) Cavero PG, Miller WL, Heublein DM et al: Endothelin in experimental congestive heart failure in the anesthetized dog. Am J Physiol 1990; 259: F312-317

18) Underwood RD, Aarhus LL, Heublein DM et al: Endothelin in thoracic inferior vena caval constriction model of heart failure. Am J Physiol 1992; 263: H951-955

19) Ishikawa $S$, Miyauchi $T$, Sakai $S$ et al: Elevated levels of plasma endothelin-1 in young patients with pulmonary hypertension caused by congenital heart disease are decreased after successful surgical repair. J Thorac Cardiovasc Surg 1995; 110 (1): 271-273

20) Cody RJ, Haas GJ, Binkley PF et al: Plasma endothelin correlates with the extent of pulmonary hypertension in patients with chronic congestive heart failure [published erratum appears in Circulation $1993 \mathrm{Mar}$; 87 (3): 1064]. Circulation 1992; 85: 504-509

21) Hiroe M, Hirata $Y$, Fujita $N$ et al: Plasma endothelin-1 levels in idiopathic dilated cardiomyopathy. Am J Cardiol 1991; 68: 1114-1115

22) Wei CM, Lerman A, Rodeheffer RJ et al: Endothelin in human congestive heart failure. Circulation 1994; 89: 1580-1586

23) Tsutamoto $T$, Wada A, Maeda $Y$ et al: Relation between endothelin-1 spillover in the lungs and pulmonary vascular resistance in patients with chronic heart failure. J Am Coll Cardiol 1994; 23: 1427-1433

24) Sakai S, Miyauchi T, Sakurai $T$ et al: Endogenous endothelin-1 participates in the maintenance of cardiac function in rats with congestive heart failure: Marked increase in endothelin-1 production in the failing heart. Circulation 1996; 93: 1214-1222

25) Sakai S, Miyauchi $T$, Sakurai $T$ et al: Pulmonary hypertension caused by congestive heart failure is ameliorated by long-term application of an endothelin receptor antagonist: Increased expression of endothelin-1 messenger ribonucleic acid and endothelin-1like immunoreactivity in the lung in congestive heart failure in rats. J Am Coll Cardiol 1996; 28: 1580-1588

26) Sakai $S$, Miyauchi $T$, Kobayashi $M$ et al: Inhibition of myocardial endothelin pathway improves long-term survival in heart failure. Nature 1996; 384: 353-355

27) Kobayashi $T$, Miyauchi $T$, Sakai S et al: Expression of endothelin-1, $\mathrm{ET}_{\mathrm{A}}$ and $\mathrm{ET}_{\mathrm{B}}$ receptors, and $\mathrm{ECE}$ and distribution of endothelin-1 in failing rat heart. Am J Physiol 1999; 276: H1197-H1206

28) Sakai S, Miyauchi T, Kobayashi $\mathrm{T}$ et al: Altered expression of isoforms of myosin heavy chain mRNA in 
the failing rat heart is ameliorated by chronic treatment with an endothelin receptor antagonist. J Cardiovasc Pharmacol 1998; 31: S302-S305

29) Sakai S, Miyauchi T, Kobayashi $\mathrm{T}$ et al: Endothelin inhibitor improves altered expression of cardiac genes in failing heart. Abstract Book of 5th International Conference of Endothelin O-37, 1997

30) Miyauchi T,Yamauchi R, Kobayashi T et al: Chronic (1 year) treatment with an endothelin receptor antagonist greatly improves survival in the hamsters with heart failure due to cardiomyopathy: increased expression of endothelin-1 mRNA in the failing heart of cardiomyopathic hamsters. Circulation 1998; 98: I-82 (abstract)

31) Yamauchi-Kohno R, Miyauchi $T$, Hoshino $T$ et al: Role of endothelin in deterioration of heart failure due to cardiomyopathy in hamsters: increase in endothelin-1 production in the heart and beneficial effect of endothelin A antagonist on survival and cardiac function. Circulation 1999; 99: 2171-2176

32) Sütsch G, Kiowski W, Yan XW et al: Short-term oral endothelin-receptor antagonist therapy in conventionally treated patients with symptomatic severe chronic heart failure. Circulation 1998; 98 (21): 2262-2268

33) Packer M, Caspi A, Charlon V et al: Multicenter, double-blind, placebo-control study of long-term endothelin blockade with bosentan in chronic heart failure: Results of the REACH-1 trial. Circulation 1998; 98 (Suppl I): I-3 (abstract)

34) Brilla CG Janicki JS, Weber KT: Cardioreparative effects of lisinopril in rats with genetic hypertension and left ventricular hypertrophy. Circulation 1991; 83: 1771-1779

35) Sadoshima J, Xu Y, Slayter HS et al: Autocrine release of angiotensin II mediates stretch-induced hypertrophy of cardiac myocytes in vitro. Cell 1993; 75: 977-984

36) Lopez JJ, Lorell BH, Ingelfinger JR et al: Distribution and function of cardiac angiotensin AT1- and AT2receptor subtypes in hypertrophied rat hearts. Am J Physiol 1994; 267: H844-H852

37) Murasawa S, Mori $Y$, Nozawa $Y$ et al: Angiotensin II Type 1 receptor-induced extracellular signal-regulated protein kinase activation is mediated by $\mathrm{Ca}^{2+} /$ calmodulin-dependent transactivation of epidermal growth factor receptor. Circ Res 1998; 82: 1338-1348

38) Hein L, Barsh GS, Pratt RE et al: Behavioural and cardiovascular effects of disrupting the angiotensin II type-2 receptor in mice. Nature 1995; 377: 744-747

39) Ichiki T, Labosky PA, Shiota $C$ et al: Effects on blood pressure and exploratory behaviour of mice lacking angiotensin II type-2 receptor. Nature 1995; 377: 748-750

40) Horiuchi M, Akishita M, and Dzau VJ: Recent progress in angiotensin II type 2 receptor research in the cardiovascular system. Hypertension 1999; 33: 613-621

41) Leri A, Claudio PP, Li Q et al: Stretch-mediated release of angiotensin II induces myocyte apoptosis by activating p53 that enhances the local renin-angiotensin system and decreases the Bcl-2-to-Bax protein ratio in the cell. J Clin Invest 1998; 101: 1326-1342 